\title{
Tracing the Genealogy of Maqāssid al-Sharī'ah Concept: A Historical Approach
}

\author{
Amir Tajrid \\ Fakultas Syariah dan Hukum Universitas Islam Negeri Walisongo Semarang - \\ Indonesia \\ amir@walisongo.ac.id
}

\begin{abstract}
This paper aims to explore the emergence, continuity and shifting of the meaning of maqāsid al-sharīah. Initially, maqūșid al-sharīah entered into the study of usūul al-fiqh and later became an independent scientific discipline. Historically, the journey of maqāsid alshari'ah has four periods, namely, the pre-codification era, the first development era, the second development era, and the maturation era as a scientific discipline. This paper is qualitative with a descriptive-analytic method, namely exploring the concept of maqāșid al-shariah in various literature. The findings in this paper are, first, the history of the emergence and development of maqāșid al-sharīah is closely related to the enforcement of Islamic law. Second, the continuity of maqūșid al-shari'ah is an ideological concept because it is based on the prevailing paradigm
\end{abstract}

Keywords: maqāṣid al-sharīah; historical tracking; mașlaḥhah; ușūl al-fiqh

\section{[]}

Tulisan ini bertujuan untuk mengeksplorasi kemunculan, ketersambungan, dan pergeseran makna maqūssid al-sharīah. Awalnya, maqāșid al-sharīah masuk ke dalam studi usūl al-figh dan kemudian menjadi disiplin ilmu mandiri. Secara historis, perjalanan maqūssid al-Sharīah dapat dikelompokkan menjadi empat periode, yaitu, era prakodifikasi, era perkembangan pertama, era perkembangan kedua, dan era pematangan sebagai disiplin ilmu. Tulisan ini bersifat kualitatif dengan metode deskriptif analitik yaitu menelusuri konsep maqāssid al-sharı̈ah dalam berbagai literatur. Adapun temuan dalam tulisan ini yaitu, pertama, sejarah kemunculan dan perkembangan maqūsid al-sharīah erat kaitannya dengan penetapan hukum Islam. Kedua, bentuk rantai maqüsid al-sharīah merupakan konsep ideologis karena berpijak pada paradigma yang berlaku.

Kata Kunci: maqāṣid al-sharīah; pelacakan sejarah; mașlaḥah; uṣūl al-fiqh 
Amir Tajrid

\section{Introduction}

The study of maqāșid al-sharīah (maqāsịid) is currently the concern of Islamic jurists. Among the main problems in the study, the forum is the chain of birth and its development into separate disciplines, such as fiqh, ușül al-fiqh, tafsìr, kaläm, and others. This question raises the pros and cons of Islamic jurists, especially those dedicated to the study of maqāșid al-sharīah. The pros and cons above can be mapped into three types: the emergence of the term maqāsid, its relation to 'ilm al-fiqh, and terms of its development. ${ }^{1}$

Maqāșid has existed since even the prophetic era and is developing until now. ${ }^{2}$ It has grown significantly in the period of sahāābah, tābi'în, tābi' al-tābi'în, and continues to be matured by Islamic jurists until today. ${ }^{3}$ This era gave birth to maqāṣid figures who represented his era. There is a chain of thought between one another. In such a context and over time, maqāșid thinking becomes very dynamic. The discourse, both from the maqāșid bearers as an independent scientific discipline and the opponents so that maqāșid remains a part of ușūl alfiqh science. ${ }^{4}$

Historical facts scattered in the works written by scholars in the field of Islamic law are a way to find the continuity of the concept of maquassid al-sharīah. Through this tracing, it is known that maqāsidid has existed long before Imam alHaramayn, who is considered to be the foundation of the concept of maqașid. This concept was then developed more comprehensively by the scholars afterwards.

The phenomenon of the continuity of the maquassid concept above encourages researchers to conduct more in-depth research. New thinking is not born without context. He was born with the influence of pre-existing ideas and

\footnotetext{
${ }^{1}$ Muhammad al-Ṭāhir Ibn 'Āshūr, Maqāșid al-Sharī'ah al-Islāmiyyah (Qatar: Wizārah al-Awqāf wa al-Shu'ūn al-Islāmiyyah, 2004), vol. II;179.

2 Iffatin Nur, Ali Abdul Wakhid, and Lestari Handayani, 'A Genealogical Analysis on the Concept and Development of Maqașid Syarī'ah', Al-'Adalah: Jurnal Syariah dan Hukum Islam 17, no. 1 (30 November 2020): 1-30, https://doi.org /10.24042/adalah.v17i1.6211; Amin Farih, 'Reinterpretasi Mașlahah Sebagai Metode Istinbāt Hukum Islam: Studi Pemikiran Hukum Islam Abū Ish̆āq Ibrāhīm Al-Shāțibī', Al-Ahkam 25, no. 1 (25 April 2015): 43, https://doi.org/10.21580/ ahkam.2015.1.25.193.

${ }^{3}$ Nūr al-Dīn Mukhtār Al-Khādimī, Al-Maqāṣsid fi al-Madhhab al-Mālikī (Riyāọ: Maktabah al-Rushd, 2003), 37.

4 'Āshūr, Maqāṣid al-Sharī’ah al-Islāmiyyah, vols II; 185.
} 
then made changes from the previous concept. Therefore, this study aims to clarify the genealogy (sanad) concept of maqāssid in terms of its continuity and change.

This research is in the form of library research that relies on print and internet resources. ${ }^{5}$ Primary data were collected from works related to maqāșid al-sharīah, which were produced from classical to modern eras. Meanwhile, secondary data were collected from works related to maqāșid al-sharīah, which were used to strengthen this theme. The approach uses a historical approach. It is used to understand the dynamics of emergence, development and changes in the meaning of maqāssid al-sharì'ah. To analyze the data, the writer used analytic descriptive. ${ }^{6}$

\section{History of the Emergence and Development of Maqāṣid}

1. The Emergence of the Maqāșid

Maqāșid appears simultaneously with the existence of Islamic law. It was at the same time as the revelation that was sent to the Prophet. Its presence is scattered in the texts and contained in regulations and directives with different degrees of clarity and designation. However, there was no urgent need to present maqāsids in writing and bookkeeping form at that time. More than that, it is represented in a particular field of study and discipline, complete with its ontology, epistemology, and axiology foundation. Of course, at that time, maqāṣid was only limited to information, data, and judgments that the scholars had in mind. They present the maqāṣid in understanding, ijtihād, and decisions which he has established. ${ }^{7}$

There are three maqāsid arguments as follows. First, the Prophet sent as a blessing and goodness for all humanity (QS. 21: 107). Second, the Koran as a guide to the path of truth (aqwām al-manāhij), the glory of life in the world and the hereafter (afdal ahwāl al-ma'äsh wa al-ma'ād), and the goodness of life (ahsan al-khawātim wa al-mawāzin) (QS. 17: 9). Third, the existence of the

5 Mestika Zed, Metode Penelitian Kepustakaan (Jakarta: Yayasan Obor Indonesia, 2008), 3.

${ }^{6}$ Nyoman Kutha Ratna, Metodologi Penelitian: Kajian Budaya dan Ilmu Sosial Humaniora Pada Umumnya (Yogyakarta: Pustaka Pelajar, 2010), 336.

${ }^{7}$ Allāl Al-Fāsī, Maqāșid al-Sharī'ah al-Islāmiyyah wa Makārimuhā (Maktabah al-Waḥdah al-'Arabiyyah al-Dār al-Bayḍā', 1963), 3. 
Koran and hadiths. The main purpose of both is to provide goodness and benefit to humans in the world and the hereafter (QS. 8: 24).

2. The Development of the Maqāșid

Maqāșid al-sharīah began to develop during the șahābah, tābi'inn, and the era after that. The development of maqāṣids in each generation has different characteristics from one another. An explanation of the story and the various attributes of this maqāsid is presented below.

a. Maqāṣid in the șahāăbah era

Maqāṣid in this era can be seen from the method used by the companions. They use an analogy (qiyās), reasoning (ra'y), ratio-legis ('illah), custom ('urf), benefits (mașlaḥah), and legal determination based on both. Aḥmad bin Ḥanbāl categorized the use of ra'y and qiyās as forms of maqāșid al-sharìah. He stated:

$$
\text { وهما من باب فهم مراد الشارع` }
$$

"Both -qiyās and ra'y-are means of knowing God's will"

b. Maqāșid in the tābi'în era

The tābi'în era is a continuation of the șahābah period. The tābi'inn are in direct contact with the șahābahs. They live by șahābah, receive hadīth, decrees, fatwas, ijtihād, methods of legal istinbāt, and legal reasons (talilät) namely maqāṣidī and istiṣlāḥi from șahạbahs. These methods are to guard and explain various legal problems. ${ }^{9}$

The determination of maqāṣid in the tābi'în era uses three methods. First, the tābi'inn determine something according to the knowledge of the șahābahs. Second, they refer to texts, mașlaḥah, and qiyās. Al-Khafif emphasized that the täbi'în in answering a problem which has no evidence in the texts, use the method of mașlaḥah, qiyās, and other forms. Al-Khafif stated:

$$
\text { نظروا فيما كانوا يراعوناه من مصالح.' - ن }
$$

${ }^{8}$ Ibn Taymiyah, Majmū'al-Fatāwā (Mamlakah Sa'ūdiyyah al-'Arabiyyah, n.d.), vols. XIX; 286.

${ }^{9}$ Shah Waliyyullāh Al-Dihlawī, Hujjatullāh al-Bāligah, (Beirut: Mu'assasah alRisālah, 1984), vols. I; 412-13; Muhammad Abū Zahrah, Tārīkh al-Madhāhib alIslāmiyah fi al-Siyāsah wa al-'Aqā'id wa Tārīkh al-Madhāhib al-Fiqhiyyah (Kairo: Dār al-Fikr al-'Arabi, 1989), 256.

10 Al-Shaykh Al-Khafīf, 'Al-Ijtihād fī al-Sharīah al-Islāmiyah', in Majallāt alIjtihād fi Sharī'ah al-Islāmiyah wa Buhūth Ukhrā (Riyad, n.d.), 221. 
"They practice to maintaining benefit"

Third, the characteristics of maqāșid in this era are divided into two schools, the Iraqi school and the Hijāz school.

On the other hand, the tābi în faced a different problem from that of their friends. Regional expansion and differences, and cultural acculturation cause these differences. Moreover, many new issues arise, but there is no legal answer in the text. This situation demands that the tābi'în perform ijtihād to find legal solutions from the readers. In doing ijtihād, the tābi'inn use their power of reason wisely and rid themselves of all worldly interests. They realize that Islamic law is not a game but for the sake of the realization of the good of the people. ${ }^{11}$

c. Maqāṣid in the era of the imām mujtahid (kubār al-a'immah)

Ibrahīm al-Nakhā'ī (d. 95 H), a teacher of Abū Hanīfah, was one of the mujtahid priests who used reasoning (ashāb al-ra'y). He used qiyās and ta'lìl. In this regard, al-Nakhā'ī stated:

$$
\text { إن أحكام ألله تعالى لها غايات هي حكم ومصالح راجعة إلينا؟' }
$$

"Indeed, the law of Allah SWT has many objectives in the form of hikmah and goodness for us".

The priests of the fiqh madhhab also use maqāsid in their ijtihād. The method of ijtihād is known as al-nazariyah al-maqāṣidi and al-ijtihād al-mașlahī. Of course, with different levels of importance and use of maqāșid. It depends on the method and the reality they come across. ${ }^{13}$

1) Abū Ḥanīfah

The full name Abū Ḥanīfah, as described by Muḥammad 'Ali alSāyis, is Nu'mān bin Thābit bin Zuțā' bin Maḥin bin Tha'labah. A person of Persian descent. He was born in $80 \mathrm{H}$ and died in 150 H. ${ }^{14}$ In his method of ijtihād, Abū Ḥanīfah did not use qiyās. This rejection of qiyās is based on four reasons, first, because of darürat. Second, the existence of the famous athar. Third, there is a general argument that must be prioritized. Fourth, there are

11 'Āshūr, Maqāṣid al-Sharī'ah al-Islāmiyyah, vols II; 180-188.

12 Al-'Ubaydī, Ibn Rushd wa 'Ulūm al-Sharī'Ah, I (Beirūt: Dār al-Fikr al-'Arabi, 1991), 102.

13 Jamāl al-Dīn 'Ațiyyah, Al-Tanẓīr al-Fiqhī, I (Mațba'ah al-Madīnah, 1987), 60.

14 Muhammad 'Aìi Al-Sāyis, Tärīkh al-Fiqh al-Isiāmī, ed. Muhammad al-Fātih bin Waliyyudin Al-Farfur, I (Damaskus: Dar al-Farfur, 2002), 207. 
stronger qiyās (istihsān).15 Fuqahā' in the Hanafi school constitutes most scholars who provide 'illah (legal reasons) in almost all legal matters. They include the discussion of 'illah and issues relating to maqāșid in the study of fiqh and its parts. ${ }^{16}$

2) Mālik bin Anas

His full name is Mālik bin Anas bin Mālik bin Abī 'Āmir al-Aṣbahī. $\mathrm{He}$ was born in Medina in $93 \mathrm{H}$ and studied with the scholars there. 'Abd al-Rahmān bin Hurmuz was his first teacher in Medina for quite a long time. ${ }^{17}$ Mālik bin Anas built his madhhab (ușūl almadhhab) on twenty arguments, namely, the text of the Koran, zāhir al-nașs (general meaning), mafhūm mukhālafah, mafhūm muwāfaqah, al-tanbīh (commemoration of the Koran), al-Sunnah, ijmā' (consensus), qiyās, 'amal ahl al-Madinah, qawl al-șahābī, istiḥsān, sadd al-dhārī'ah, murā'àt al-khiläf, istiḥbāb, al-mașālị̣ almursalah (istișläh), and shar' man qablanā. Of the twenty principles of Madhhab, five basics have a significant influence and have substantial differences with other schools of thought. The five are 'amal ahl al-Madīnah, al-mașāliḥ al-mursalah (istișlāhn), qawl al-șaḥābī, al-Sunnah, and istihssān. ${ }^{18}$

3) Al-Shāfi'ì

His full name is Abū 'Abdullāh Muhammad bin Idrīs bin 'Abbās bin 'Uthmān bin Shāfi'ī al-Hāshimī al-Mutțalibī. He was from the Bani Muțtalib bin 'Abdi Manāf. He met the Holy Prophet at 'Abdi Manāf. He was born in Guzzah (Gaza), the region of Sham, in 150 H. Regarding the basics of his madhhab (ușull al-madhhab), in al$\mathrm{Umm}$, he stated that the source of law is the Koran and al-Sunnah. If not found in both, then with qiyās. If you find the hadith of the Holy Prophet and his sanad is correct (sahihh), then that is the legal answer (al-muntahī). For him, ijmā' is stronger than hadìth ahad

${ }^{15}$ Al-Sāyis, 213-14.

16 Ika Yunia Fauzia Fauzia and Abdul Kadir Riyadi, Prinsip-Prinsip Ekonomi Islam: Perspektif Maqāșid as-Syarīah, (Jakarta: Prenadamedia Group, 2015), 56.

${ }^{17} \mathrm{He}$ has the laqab Abū Dāwud and a hăfiz and qāri' Madīnah. He met Abū Hurayrah and took hadīth from him. He is very knowledgeable about the history of the origins of Arabia (ansāb al-'Arab), reliable, and broad knowledge. He died and was buried in Alexandria in $117 \mathrm{H}$. See for more details in Khayr al-Din AlZurkuli, Al-'A'Lam, (Beirūt: Dar al-'Ilm li al-Malayin, n.d.), vols. III; 340.

${ }^{18}$ Al-Sāyis, Tārīkh al-Fiqh al-Islāmīi, 226-28. 
(khabar al-munfarid). Hadith practice is based on the explicit meaning (zāhir) of it. If the meaning of hadith is unclear or contains multiple interpretations (ihtimā $l$ ), then the meaning closest to the explicit meaning takes precedence. If several hadiths are of the same degree, then the truest sanad is the main one. Whereas hadith munqați' has no value at all except hadith munqați' Ibn al-Musayyab. ${ }^{19}$

The explanation above provides an understanding that in addition to the Koran and al-Sunnah, ijmā' and qiyās are sources of law used by al-Shāfi'î. He did not mention al-mașāliḥ almursalah as the source of direction, thus proving that al-Shāfi'i rejected him. However, he still includes the dimension of benefit in every legal decision. For example, when he spoke of 'illah as one of the pillars of qiyās. This dimension of benefit (mașlahah) is seen in his old opinion (qawl qadim) and new opinion (qawl jadid $)$.

Al-Shāfi'ì does not use hadìth mursal except hadìth mursal Ibn al-Musayyab whose validity has been agreed. He was the first to give hadith mursal a disability rating. This statement contradicts the opinion of Sufyān al-Thawrī, Mālik bin Anas, and the followers of the Hanafi school of thought. Al-Shāfi'ì also did not use qawl alșahābì. The reason is, qawl al-șaḥābì may arise from wrong ijtihād results. He also did not give the same assessment to hadith who was left by șahābah, other than șahābah, or residents of an area because they were considered disabled.20

Apart from rejecting hadìth mursal and qawl al-șaḥābi, AlShāfi'ì also rejects istihsān as evidence. He denied and left the istiḥsān which were widely used by the Māliki and Ḥanafi schools. He said: من استحسن فقد شرع, (whoever uses istihsān, he plays the

20 Al-Sāyis, 238. 
law). ${ }^{21}$ Specifically, al-Shāfi'î wrote a rebuttal to the istihsāan entitled Ibțāl al-Istihssān.22

About qiyās, he does not apply it unless the 'illah is clear (mundabit). He also refused to make collisions with 'amal ahl alMadinah. This refusal he wrote in detail in the book of al-Umm. ${ }^{23}$ In this book, there are differences of opinion between al-Shāfi'i and other scholars on several fiqh issues. ${ }^{24}$

4) Aḥmad bin Ḥanbal

His full name is Abū 'Abdillāh Aḥmad bin Hanbal bin Hilāl bin Asad al-Shaybānī al-Marwazī al-Baghdādī. ${ }^{25}$ Ibn al-Qayyim, in I'läm al-Muwaqqi'în, asserts that the fatwa of Ahmad bin Hanbal is constructed in several ways as follows. ${ }^{26}$

a) Religious texts (al-nușūss) include Koran and hadīth marfü'

b) The sahābah fatwa. If one fatwa is found from a sahābah and there is no rejection from another șahābah, then one cannot turn to that other șahābah fatwa. Such șahābah fatwas cannot be said to be ijmä'. Sahābah fatwas must be preceded by action ('amal), ra'y (reasoning), and qiyās (analogy).

c) When there is a difference of opinion among the șahābahs, one must choose the closest statement to the Koran and al-Sunnah and must not be out of his thought.

d) Using the methods of al-mașāliḥ al-mursalaḥ (istișlāḥ) and hadith da'îf, when there are no arguments against them.

e) Qiyās is only used in a forced state (darūrāt), i.e. when hadith, qawl șaḥābī, al-mașāliḥ al-mursalah (istiṣlāh), and ḥadìth ḍa'îf are not found.

21 'Abd al-Wahhāb Khallāf, Mașādir al-Tashrī' fī Mā lā Nașșa Fīh (Kuwait: Dār al-Qalam li al-Nashr wa al-Tawzì', 1994), 89; Maskur Rosyid, Implementasi Konsep Maslahat Al-Ṭüfi dalam Fatwa MUI (2005-2010), 1st ed. (Magelang: Ngudi Ilmu, 2013), 4.

22 Muhammad Yūsuf Mūsā, Tārīkh al-Fiqh al-Islāmī (Kairo: Dār al-Kutub alHadīthah, 1958), 259; Al-Sāyis, Tārīkh al-Fiqh al-Islāmī, 238.

${ }^{23}$ Al-Sāyis, Tãrīkh al-Fiqh al-Islāmī, 239.

24 'Abd al-Hayy Ibn al-'Imād Al-Hanbalī, Shadharāt al-Dhahab fi Akhbār Man Dhahab (Kairo: Maktabah al-Qudsi, n.d.), vols. VII; 277-88.

${ }_{25}$ Al-Sāyis, Tārīkh al-Fiqh al-Islāmī, 242.

${ }^{26} \mathrm{Ibn}$ al-Qayyim Al-Jawziyyah, I'lām Al-Muwaqqi'īn 'an Rabb Al-'Ālamìn, ed. Muhammad Muḥyiddin 'Abdul Majīd (Beirūt: Dār al-Fikr, n.d.), 32. 


\section{Tracing the Concept of Maqāṣid al-sharī'ah}

1. The term maqāssid al-sharīah in the era of the Prophet

The era of risālah ended when the Prophet died. In that era, maqāsid appeared at the same time as the law. The Holy Prophet, in this case, conveyed and established legal status. Maqāsid is a consideration and a basis for doing charity and exploring the law. Maqāṣid exists in every word, deed, and stipulation of the Prophet, and the strengthening of practice by șahābahs. ${ }^{27}$

In this era, maqāsid is depicted in the sunnah. This existence is evident from several 'illah, hikmah, and sirr associated with specific laws. For example, the prohibition of keeping sacrificial meat for more than three days as food supplies for the Bedouins ( $a l-a^{\prime} r a \bar{b} b \bar{l}$ ) needs it. Then the Prophet allowed it when they did not need it anymore. Another example is the reason ('illah) obligation to ask permission (al-isti'dhān) to enter someone else's house to maintain dignity and avoid disclosing household secrets prohibited from being seen by others. ${ }^{28}$

\section{Expressions of maqāșid al-sharī'ah in the sahābah era}

The expression of the maqāsid in this era is more evident than in the previous period. This clarity is because the situation and conditions are different from the time of the risālah. In this era, the need to reveal and explain new problems and events due to the expansion of Islamic territory is urgent. The facts prove that șahābahs have carried out the maintenance of maqāssid in some legal decisions. They put forward the principle of ease (al-taysir $)$, lightness ( $a l-$ takhfif), softness (al-rifq), avoiding stiffness (al-taysir, al-tashaddud, al-tanațtu', al-ta'ammuq), avoiding excess in giving excessive burdens (al-mubālaghah; altakalluf), and so on. The actions of these friends are by the meaning of the hadith, which prohibits providing undue burdens. Tanattu' and ta'ammuq have the same purpose, namely rigid and harsh in words and deeds. Meanwhile, takalluf means giving a responsibility beyond one's ability. These three words (tanattu', ta'ammuq, and takalluf) are terms related to the maqāssid used at that time.

3. Several terms refer to the meaning of maqāșid

27 'Āshūr, Maqāsid al-Sharī'ah al-Islāmiyyah, 185-88.

28 Muhammad Muṣțafā Shalabī, Ta'līl al-Ahkām (Beirut: Dār al-Nahḍah al'Arabiyah, 1981), 23-24; Muhammad Shārīf Al-Rahamūni, Al-Rukhas alFiqhiyyah min al-Qur'ān wa al-Sunnah al-Nabawiyyah (Tunis: Mațba'ah al'Arabiyyah, 1986), 344-45; Al-Dihlawi, Hujjatullāh al-Bāligah, vols I; 30. 
Amir Tajrid

Before describing the genealogy of the maqāsid al-sharīah concept, the author first explains the terms used by scholars in expressing the sense of maqāsisid al-sharī'ah. Classical scholars used different words when describing the nature of maqāșid. The use of these other terms and phrases has a different level of relevance to the designation, name and meaning of maqāșid al-sharī'ah. Their primary attention is focused on the method of presenting maqāṣid al-sharīah and its application in performing ijtihād. They do not try to codify (tadwin), define (ta'rïf), depiction (tamthīl), basic argumentation ( $t a$ 'ṣill), etc.

The following descriptions are terms often used by scholars, classical and modern. They use these terms to describe the purpose of the lawmaker (alShāri'), the purpose of revelation (maqșūd al-wahy), the benefit of humanity (mașälih al-khalq). Besides that, they are also used to shape the content, theory, and development of this discipline. Some of these terms are as follows.

a. الحكمة المقصودة بالشريعة (hikmah intended by sharī'ah).29

b. المصيلحة (al-mașlaḥah, benefit). ${ }^{30}$

c. نفي الضرر, رفع الضرر, وقطع الضرر (negating, eliminating and canceling the danger) ${ }^{31}$

d. دفع المشقة ورفع المشققة (rejects and removes difficulties). ${ }^{32}$

e. رفع الحرج والضيق وتقرير التيسيروالتخفيف (eliminates difficulties and constraints while establishing convenience and lightness) ${ }^{33}$

f. العلل الجزئية للأحكام الفقهية ('illal which is particular for the rule of law). 34

${ }^{29}$ Abū al-Wālid Muhammad Ibn Rushd, Fașl al-Maqāl wa Taqrīru ma Bayn alSharī'ah wa al-Hikmah Min al-Ittișāl (Beirūt: Dār al-Mashriq, 1982), vol. IV; 49; Maskur Rosyid, 'Membincang Kembali Hubungan Syariah dan Filsafat', Istigha 2, no. 1 (2019): 53-54.

30 Al-Jawziyyah, I'lām al-Muwaqqi'īn 'an Rabb al-'Ālamīn, vol. III;14.

31 Abū al-Wālid Muhammad Ibn Rushd, Bidāyah al-Mujtahid wa Nihāyah alMuqtașid (Beirut: Dār al-Fikr, n.d.), vols, II; 335.

32 Abū Bakr Ibn Al-'Arabī, Ahkām al-Qur'ān (Beirūt: Dār Al-Kutub Al'Ilmiyyah, 2003), vols I; 200; Rushd, Bidāyah al-Mujtahid wa Nihāyah alMuqtașid, vols I; 143.

33 Al-Rahamūni, Al-Rukhaș al-Fiqhiyyah min al-Qur'ān wa al-Sunnah alNabawiyyah, 120-21.

${ }^{34}$ Initially, the use of the word 'illat' referred to the meaning of hikmah and mașlahah. However, on the next journey, when it is in the hands of ușūliyyūn, it leads to understanding the nature / state that is real / clear and measurable. The truth is that the word 'illat is used in two senses which have a real connection. 
g. ما يتفرع عن العلة كالموجب والسبب والمؤثر وغيره (other terms of 'illah namely al-müjib, al-sabab, al-mu'thir, and others). ${ }^{35}$

h. معقولية الشريعة وتعليلاتها وأسرارها (logic, consideration, and sharī'ah secrets).

i. لفظ المعاني (ma'ānī means meaning). The scholars express the word ma'ānī to denote the goal (maqāṣid) and benefit (mașāliḥ) contained in shari'ah and the laws of Allah SWT. ${ }^{36}$

j. كلمات الغرض والمرادوالمغزى (purpose words meaning substance). The scholars expressed maqāṣid al-sharī'ah with these expressions. ${ }^{37}$

4. Maqāșid al-Sharī'ah in the terminology of the scholars

Initially, none of the scholars defined maquassid al-sharīah. The definition of maqāṣid al-Sharīah only emerged when contemporary scholars gave its meaning. Terms like, المعانى, الحكم, الغاية, الاسرار, الغايات, الشارع, التشريع, المصلحآ are keywords in several definitions. The following are maqāṣid terms put forward by scholars.

a. Muḥammad Ṭāhir Ibn ‘Āshūr (1366 H), defines maqāṣid as several meanings and pearls of hikmah described by the lawmaker [alShäri] in the whole or most of the laws that are enacted. These meanings and hikmah do not refer to a particular type of sharia law. Included in this category are some characteristics and general objectives of sharia, as well as many meanings that cannot be abandoned in the application of shara' [al-tashrī] law. Likewise, many meanings and pearls of hikmah are also not explained in their entirety in fiqh, but several meanings and pearls of hikmah are explained in most laws. ${ }^{38}$

That is, on the one hand, 'illat is related to a clear and measurable nature / state, on the other hand' illat is also related to the disclosure of the hikmah of this nature / state, demeanor (mașlahah), and its enactment (masyru'iyah). Abū Ishāq Ibrāhīm bin Mūsā Bin Muhammad Al-Shāțibī, Al-Muwāfaqāt fí Ușūl alSharì'ah (Beirut: Dār al-Ma'rifah, 1975), 265; Ahmad Al-Raysūnī, Nazariyyāt alMaqāșid 'Ind al-Imām al-Shāțibì (Rabāṭ al-Magrib: Dār al-Amān, 2003), 10.

35 Shalabī, Ta'līl al-Ahkām , 158.

${ }^{36}$ Al-Raysūnī, Nazariyyāt al-Maqāṣid 'Ind al-Imām al-Shātịib̄i, 14.

${ }^{37}$ Al-Raysūnī, 15.

38 The terminology of Ibn 'Asyur has been quoted by a number of other maqāṣid thinkers such as: al-Khādimi, Muhammad al-Habīb Ibn al-Khawjah, and Abdul Azīz Ibn 'Abd al-Raḥmān Ibn 'Alī ibn Rabī’ah Nūr al-Dīn Mukhtār Al- 
b. 'Allāl al-Fāsi states that maqāșid al-Sharī'ah is the aim and secret of the law that has been laid by the lawmaker [al-Shäri] ${ }^{39}$

c. Raysūni defines maquassid al-sharīah with the objectives that alShāri' has laid out to be investigated for the benefit of humankind. ${ }^{40}$

d. Muhammad bin Sa'ad al-Yūbī defines it with several meanings, hikmah, and the like that are guarded by al-Shāri' in enacting laws, both general and specific, which aim for the benefit of humans. ${ }^{41}$

e. Al-Khādimy defined maqāșid with several meanings described in shara' law and the meanings that resulted from it. Sometimes, several meanings are in the form of hikmah: juz'i (particular), and in the form of benefit, kulli (general). A number of these meanings have the same goal, namely ensuring obedience to Allah SWT and realizing the benefit of humankind in this world and the hereafter. ${ }^{42} \mathrm{Al}$-Khādimī emphasized that there are several types of benefit, namely mașlahah fardiyyah and mașlahah ämmah, mașlaḥah which are qaț'ì-yaqīnì and zannī-ihtimālì , and so on.43

\section{Continuity of the Concept of Maqāṣid al-Sharī'ah}

The theory of Continuity and Change states that existing concepts influence the emergence of a concept. In this context, Karl Mannheim (Hungary, 18931947), as quoted by Muhyar Fanani, stated that new thoughts, concepts and theories can be ideological or utopian when linked to pre-existing thoughts, concepts and theories. When new thoughts, concepts and theories are based on the prevailing paradigm, that thought is called ideology, so that new thinking is

Khādimī, 'Ilm al-Maqāṣid al-Shar'iyyah (Riyad: Maktabah al-'Ubayyikān, 2001); Muhammad al-Habīb Ibn Al-Khawjah, Bayn 'Ilmay Ușūl al-Fiqh - Maqāșid alIslämiyyah (Qatar: Wizārat al-Awqāf wa Al-Shu'ūn al-İslāmiyyah, n.d.); 'Ảlī Ibn Rabī'ah, 'Ilm Maqāṣid al-Shārī'Ah (Riyāḍ: al-Mamlakah al-'Arabiyyah alSu'ūdiyyah, 2002).

${ }^{39}$ Al-Fāsī, Maqāșid al-Sharīah al-Islāmiyyah wa Makārimuhā, 3.

${ }^{40}$ Al-Raysūnī, Nazariyyāt al-Maqāșid 'Ind al-Imām al-Shāțibī, 7.

${ }^{41}$ Muhammad Sa'ad Al-Yūbī, Maqā̇șid al-Sharī'ah al-Islāmiyyah wa 'Alāqatuhā bi al-Adilliah al-Shar'iyyah (Riyad: Dār al-Hijrah, 2002), 37.

${ }^{42}$ Al-Khādimī, 'Ilm al-Maqāșid al-Shar'Iyyah, 17.

${ }^{43}$ Nūr al-Dīn Mukhtār Al-Khādimī, Al-Maqāșid al-Shar'iyyah wa Șilatuhā bi alAdillah al-Shar'iyyah wa al-Muștalahạăt al-Ușūiliyyah (Riyad: Dār Isybilia, 2003), 29. 
ideological. This section will present a chain of concepts of maqāșid al-sharī'ah based on a specific period based on the description above.

1. Pre-codification (prophetic era until early III century $\mathrm{H}$ )

The pre-codification era includes the era of risālah, șahābah, täbi'inn, and the a'immāt al-madhāhib. Traces of maqāșid al-sharīah have appeared in this era, along with the existence of shari'ah and its instructions. However, in this era, maqāșid al-sharīah is categorized as scientific facts rooted in the Prophet (s), the șahābahs, and the scholars. Maqāșid al-sharīah is scattered among his fatwas, sources of reference, works, and thoughts. This is because the word maqāșid is intertwined with the word syari' $a h^{44}$

The existence of maqāsid al-sharīah in this era has not shown the perfect format and structure to be called a concept or theory. It is only a marker of the birth of general maqāsid thoughts. It does not have a basis and rules and is still free from bookkeeping, division and argumentation. This condition becomes the basic assumption that the development of maqāșid in the next period depends on the continuity of scientific work, the continuity of ijtihād, and the establishment of law (tashrī). This is the most tangible result of scientific work in the current era of fiqh.

The existence of maqāsid, which is only limited to information, data, and legal rulings for the ulama, resulted in two important facts. First, maqāșid until the end of the 3rd century $\mathrm{H}$ has not been of particular concern and has not become a separate scientific topic. The maqa șid understood by the scholars is still shrouded in their studies of hikmah, 'illah, munāsabah, and ma'nā. Therefore, maqāsid can only be found in a number of the methods of reasoning they use, such as qiyās, istiḥsān, and considerations of benefit. Second, the terms maqāșid and maqāșidiyyūn, which are based on concepts or theories and experts in the field of maqāssid have not been found. Meanwhile, in that era, the terms tafsìr-mufassirūn, fiqh-fuqahä', ușül-ușūliyyūn, which were based on a concept or theory from experts in these fields, already existed.

2. The era of the first development (early 3rd to 5th century AH): The emergence of the maqāșid theory

44 'Ațiyyah, Al-Tanzīir al-Fiqhī, 69. 
Amir Tajrid

The development of maqāṣids during this era was not clearly defined as it is known today. However, scholars in this era have expressed the early theories of maqāșid al-sharīah. Among them are:

a. Al-Ḥākim al-Tirmīdhī Abū 'Abdillāh Muḥammad bin 'Ali (d. 296 H/908 M). Al-Hākim al-Tirmidhi was not a jurist (faqīh) and ușūlì, but he was better known as a Sufi and a philosopher. However, he first used the term maqāșid and made it the title of his work. Among these books are: al-Ṣalāh wa Maqāșiduhā, al-Hajj wa Asrāruh, al-'Ilāl, 'Ilāl al-Sharī'ah, and 'Ilāl al-'Ubüdiyah. ${ }^{45}$

b. Abū Zayd al-Balkhī (d. 322 H/933 M) was the first character to reveal the maqāșid mu'āmalah, al-'Ibānah 'an 'Ilāl al-Diyānah (Explanation of the Purposes Behind Worship Practices). He examines the maqāșid behind the Islamic juridical laws. He also wrote a remarkable book about benefit with the title Mașālih alAbdān wa al-Anfus (Some Benefits of Body and Spirit). He explained that Islamic practices and laws contribute to health, both physically and mentally. ${ }^{46}$

c. Abū Manșūr al-Matūridī (d. $333 \mathrm{H}$ ) who is better known as the kalam scholar. He was the founder of the al-Matūridiyah school, which the Hanafi school of thought followed. He is one of the imām ahl al-sunnah who has several works in the field of ușul al-fiqh. Among his works that talk about maqāșid is Ma'khadh alSharī'ah. ${ }^{47}$

d. Abū Bakr al-Qaffāl al-Shāshī (d. 365 H) is one of the central figures of classical ușūl al-fiqh. He is a follower of al-Shāfi'ì and one of the writers of al-Risālah. Among his works related to maqāssid alsharīah is Mahāsin al-Sharī'ah (The beauties of the Shari'ah). According to him, one cannot possibly bring out the beauties in Islamic law except by exposing hikmah and objectives. ${ }^{48}$ In the book, he wrote an introduction (about 20 pages) and continued with the division of chapters as in traditional fiqh books. He mentions each law briefly and elaborates on the maqāșid al-

${ }^{45}$ Al-Raysūnī, Naẓariyyāt al-Maqāșid 'Ind al-Imām al-Shātibīi, 27-28.

46 Jasser Awdah, Membumikan Hukum Islam Melalui Maqāșid As-Syarī'ah (Bandung: Pustaka Mizan, 2015), 46.

${ }^{47}$ Al-Raysūnī, Nazariyyāt al-Maqāșid 'Ind al-Imām al-Shāțibī, 28-29.

48 Ibn al-Qayyim Ál-Jawziyyah, Mif́tāh Dār al-Sa'ādah wa Manshūr Wilāyāt al'Ilm wa al-Irādah (Beirut: Dār al-Kutub al-'Ilmiyyah, n.d.), 42. 
shari'ah and the hikmah behind them. This work marked an essential step in the development of the theory of maqāsid alsharī'ah. $^{49}$

e. Abū Bakr al-Abharī (d. $375 \mathrm{H}$ ) is a character who combines fiqh with ușūl al-fiqh. The two fields he compiled simultaneously. AlKhāțib al-Bagdādī emphasized that al-Abharī has several works that review the Mālikì school of thought by providing support for the arguments used and rejecting all opposing views. ${ }^{50}$ Among the works of al-Abharī are Kitāb al-Ușūl, Ijmā' Ahl al-Madīnah, and Mas'alāt al-Jawāb wa al-Dalā'il wa al-'Ilal. The last book has an essential meaning in topics related to the study of maqāssid alsharì'ah, ${ }^{51}$

f. Al-Baqillāni (d.403 H), he was nicknamed Syaykh al-Sunnah wa Lisān al-Ummah (al-Sunnah teacher and mouthpiece of the ummah). He is categorized as Mujaddid al-Mi'ah al-Rābi'ah (reformer of the 4th century H). If al-Shāfi'i was the first compiler of the science of Ușūl al-fiqh, then al-Baqillāni was the first to expand the scope of the study material of ușül al-fiqh science. He incorporated the elements of kalam science into it, namely the study of tahsin wa taqbīh (good and bad). ${ }^{52}$ Evidence that shows that al-Baqillāni made a significant contribution to the development of the study of ușūl al-fiqh is through his work entitled Al-Taqrīb wa al-Irshād fi Tartīb Turuq al-ijtihād. This book he then summarized himself into two, namely Al-Irshād alMutawassit and Al-Irshād al-Saghīr. ${ }^{53}$

3. The second development era (5th century to 8th century AH): The emergence of Islamic legal philosophy

'Abd al-Rahmān bin Bayyah stated that the fifth century was the century where Islamic legal philosophy emerged. In this century, literal and nominal methods are considered incapable of answering the complexity of problems faced by the ummah. The development of the theory of al-mașlahah al-mursalah

\footnotetext{
${ }^{49}$ Awdah, Membumikan Hukum Islam Melalui Maqāșid As-Syarī'ah, 47.

50 Al-Qāḍī 'Iyād, Tartīb al-Madārik wa Taqrīb al-Masālik li Ma'rifāt 'A'lām Madhhab Màlik (Wizārat al-Awqāf al-Maghrabiyyah, n.d.), vols. VII; 183-92.

51 'Iyāḍ, 185.

52 Al-Raysūnī, Nazariyyāt al-Maqāṣid 'Ind al-Imām al-Shāțibī, 31.

53 'Iyāḍ, Tartīb à̀-Madārik wa Taqrīb al-Masālik li Ma'rifāt 'A'lām Madhhab Mālik, 69-70.
} 
was carried out to cover the shortcomings of the qiyās method and to encourage the emergence of the maqāsidid al-sharīah theory.

Al-Burhān fi Ușūl al-Fiqh by al-Juwaynī is the first work of ușūl al-fiqh which introduces the theory of al-darüriyah (emergency level; al-kulliyyah alkhamsah). This theory is similar to Abraham Maslow's theory of levels of need. According to al-Juwaynī, there are five levels of emergency, namely, first, relating to ḍarūrāt (necessity), such as qișāṣ. It was second, related to al-hājāt al'ämmah (public interest), such as leasing contracts and third, related to al-tahalli bi al-mukarramāt wa al-takhallī al-naqā'iḍihā (moral behavior), such as cleanliness or purity and fourth, related to al-mandūbāt (suggestions). Fifth, related to mã lā yaẓhar ta'lìl wădịh wa la maqșad muhaddad (something that is not included for a specific reason). According to him, the purpose of establishing Islamic law is for al-isismah, namely the maintenance of faith, soul, mind, family and property. ${ }^{54}$

Abū Hāmid al-Gazzālī (d. 505 H/1111 M), in the book Al-Mustașfā, further developed the maqāsid theory. He called it al-kulliyyāt al-ḍaruriyyat wa alistișlāh. ${ }^{55} \mathrm{He}$ arranged the levels of emergency (tartīb al-darūriyyāt), namely religion, soul, mind, descent, and property. He was the first to use the term alhifz (guardianship). He refuses to give legitimacy to any maquassid or masāalih, and even he calls it pseudo benefit (al-mașälih al-Mawhümah). ${ }^{56}$ According to him, maqāșid has been tested by texts and maqāșid is not something that gets the legitimacy of the texts. ${ }^{57}$

Apart from these two figures, several maqāșid thinkers emerged from the mainstream. They try to get out of existing study patterns and avoid repeating studies. They are not mastering of ușūl (ușūliyyūn) in the strict sense. They are both ușūl experts and jurists (al-ușūliyyūn al-fuqahō). It is just that their study of maqāșid is still fleeting in the middle of discussion around the issue of fiqh or ușūl al-fiqh. Maqāșid thinkers of this category are; 'Izz al-Dīn bin 'Abd al-Salām (d. 660

54 Al-Juwaynī, Al-Burhān fì Ușūl al-Fiqh, ed. 'Abd al-'Aẓīm Al-Dīb (alManshurah: al-Wafā', 1998), vols. II; 621-22, 747; Saim in his writing's states that maqāșid al-sharī'ah includes seven things, namely religion, soul, mind, descent, property, honor, and state. Saim Kayadibi, "The State as an Essential Value (Darūriyyāt) of the Maqāșid al-Sharī'ah', Ahkam : Jurnal Ilmu Syariah 19, no. 1 (9 July 2019), https://doi.org/10.15408/ajis.v19i1.6256.

55 Abū Hāmid Muhammad Ibn Muhammad Al-Ghazzālī, Al-Mustasfā min 'Ilm al-Ușūl (Beirut: Dār al-Fikr, n.d.), vols İ; 139.

${ }^{56}$ Al-Ghazzālī, vols I; 172.

57 Jasser Awdah, Maqāșid Dalīlun li al-Mubtadī (London: al-Ma'had al-'Ālamī li al-Fikr al-Islāmī, 2011), 45-46. 
H./1261 H.), Shihāb al-Dīn al-Qarāfi (d. 684 H. / 1285 AD), Ibn Taymiyah, Ibn alQayim al-Jawziyah (d. 751 H/1350 M).58

After 'Izz al-Dīn bin 'Abd al-Salām, there were figures who were regarded as pioneers in the study of maqāssid al-sharīah. They try to make it a separate and independent scientific discipline from the science of ușūl al-fiqh with its definition, discussion framework and target of study. Al-Shātibì (d. 790 H/1388 M), a thinker from Andalusia (Spain) is one of the pioneers of the maqāsid alsharī'ah. ${ }^{59}$ In the book of Al-Muwäfaqāt, he has written a particular chapter on maqāssid comprehensively. In this context, he deserves to be called the figure who initiated the science of maqāsid al-sharīah. He has laid the foundation for this study by categorizing the maqāṣid into two parts; maqāssid al-shāri' and maqāșid al-mukallaf. Al-Jayyidi stated that such a study had never existed before. This study should be a separate work outside the book Al-Muwāfaqāt. Al-Shātibi's scientific work in the field of maqāsid can be likened to the scientific work done by al-Shāfi'i in the field of ușül al-fiqh. ${ }^{60}$

4. Era of maturation (16th century H until now): Maqāșid al-sharīah as independent science ${ }^{61}$

After al-Shāțibī, scientific discourse regarding maqūṣid al-Sharī'ah as an independent scientific discipline had experienced a vacuum. Until the end of the $\mathrm{XX}$ century $\mathrm{AD}$, the scientific discourse was raised again. Two reformers emerged, namely Muḥammad Țāhir ibn 'Āshūr (d. 1393 H/1973 M), a thinker from Tūnis and Muhammad Allāl al-Fāsī (d. 1394 H/1974 M), a thinker from Morocco (Magribī).62 The two of them continued the mega project of al-Shāțibì. Both of them not only poured their ideas into a particular book about maqāsid al-sharī’ah but also into other books. 'Allāl al-Fāsy expresses his ideas in Maqāșid

${ }^{58}$ Abū 'Abdullāh Muhammad Al-Maqrī, Al-Qawāid, ed. Ahmad bin 'Abdullāh bin Hāmid (Makkah: Ma'had al-Buhūth wa Ihyā' al-Turāth al-Islāmī Jāmi'ah Ummu al-Qurā, n.d.), vols I; 53; Al-Khādimī, Al-Maqāșid fì al-Madhhab al-Mālikī, 29.

59 Al-Khādimī, Al-Maqāșid fì al-Madhhab al-Mālikī, 29; Alfa Syahriar and Zahrotun Nafisah, 'Comparison of Maqasid Al-Shari'ah Asy-Syathibi and Ibn 'Ashur Perspective of Usul Al-Fiqh Four Mazhab', Ulul Albab: Jurnal Studi dan Penelitian Hukum Islam 3, no. 2 (30 April 2020): 185, https://doi.org/10. 30659/jua.v3i2.7630.

60 'Umar Al-Jayyidī, Al-Tashrī' al-Islāmī Ușūluh wa Maqāṣiduh (Manshūrāt 'Ukāz: Mațba'ah al-Najāḥ al-Bayḍā', 1987), 30.

${ }^{61}$ Mahsun Mahsun, 'Rekonstruksi Pemikiran Hukum Islam Melalui Integrasi Metode Klasik dengan Metode Saintifik Modern', Al-Ahkam 25, no. 1 (25 April 2015): 1, https://doi.org/10.21580/ahkam.2015.1.25.191.

${ }^{62}$ Al-Khādimī, Al-Maqāșid fí al-Madhhab al-Mālikī, 30. 
Amir Tajrid

al-Islāmiyah wa Makārimuhā, Difā' an al-Sharīah, and al-Naqd al-Dhātī. Meanwhile, Ibn 'Āshur poured his ideas into Maqāșid al-Sharī'ah al-Islāmiyah, Tafsìr al-Tahrīr wa al-Tanwīr, Ușūl al-Nizām al-Ijtimā'ì, Alaysa al-Șubh bi Qarīb, and Kashfal-Mughț.

After these two figures, the study of maqāșid al-sharīah was increasingly prevalent in various Islamic worlds. Nūr al-Dīn Mukhtār al-Khādimī from Tunis and Ahmad al-Raisūnī from Morocco are two crucial figures after Ibu 'Āshur and 'Allāl al-Fāsī. ${ }^{63}$ Through both ideas and ideas, currently, the study of maqāṣid alsharī'ah continues to move dynamically. Al-Khādimi is a professor of maqāsid at the University of Zaitūnah al-Ma'mūr-Tunis. He is also active as a speaker in national and international forums in the field of maqāșid al-sharī'ah studies. He was the successor to Ibn 'Āshur's idea who tried to make maqāșid an independent scientific discipline. He proved his seriousness by writing books in the field of maqāșid al-sharī'ah. Meanwhile, Raysūni is a maqāșid thinker and senior lecturer at Mohammad V Rabat University, Morocco. Like al-Khādimī, he also poured the ideas of maqāṣid al-sharīah into several books. ${ }^{64}$

The era of the first development (early 3rd to 5 th century $\mathrm{H}$ ): The emergence of the maqāssid theory Al-Hākim al-Tirmīdhī (d. 296 H/908 M), Abū Zayd al-

Pre-codification (prophetic era until early III century $H$ )
Balkhī (d. 322 H./933 M.), Abū Manșūr al-Matūridī (d. 333 H.), Abū Bakr al-Qaffāl al-Shāshī (d. 365 H), Abū Bakr al-Abharī (d. 375 H), and Al-Baqillāni (d. $403 \mathrm{H}$ )
Era of maturation (16th century $H$ until now): Maqāṣid as independent science

Ibn 'Āshūr (d. 1393 H/1973 M) and 'Allāl al-Fāsi (d. 1394 H/1974 M) $\rightarrow$ AlKhādimī $(1382$ H/1963 M) and Raysūnī (1372H/1953 M)

\section{I}

The second development era (5th to 8th century $H$ ): The emergence of Islamic legal philosophy Imām al-Ḥaramayn (d. 478 H), Al-Gazzālī (d. 505 H), AlRāzī (d. 606 H), Al-Āmidī (d. 637 H), Ibn al-Hājib (d. 646 H), Al-Bayḍāwī (d. 685 H), Al-Isnawī (772 H), Ibn alSubkī (d. $771 \mathrm{H}) \rightarrow$ 'Izz al-Dīn bin 'Abd al-Salām (d. 660 H/1261 M), Al-Qarāfī (d. 684 H/1285 M), Ibn Taymiyah (d. $728 \mathrm{H} / 1328 \mathrm{M}$ ), and Ibn al-Qayim al-Jawziyah (d. 751 H/1350 M) $\rightarrow$ Al-Shāțibī (d. 790 H/1388 M)

Figure 1. The conceptual journey of maqāṣid al-sharīah

${ }^{63}$ Ahmad Al-Raysūnī, Al-Fikr al-Maqāṣidì: Qawā'iduh wa Fawā'iduh (Beirut: Dār al-Hādī, 2003), 123.

${ }^{64}$ Usman Betawi, 'Maqashid Al-Syariah Sebagai Dasar Hukum Islam dalam Pandangan Al-Syatibi dan Jasser Audha', Jurnal Hukum Responsif 6, no. 6 (2019): 32-43. 
Tracking the Genealogy of Maqāṣid...

\section{Conclusion}

This study found that the journey of the maqāsid al-sharīah was divided into four eras through historical tracing. First, the pre-codification era that occurred in the prophetic era until the early 3rd century H. In this first era, the names of maqāșid figures did not explicitly display. Second, the era of the first development, namely at the beginning of the 3rd century $\mathrm{H}$. to the $\mathrm{V} \mathrm{H}$. other. Third, the second development era, namely in the V H. to VIII H. century. The emergence of Islamic legal philosophy marked this era. Fourth, the era of maturation, namely the XIV H century until now. This era is the era of the independence of maqāṣid al-sharīah.

The maqāsid concept of figures representing their era was initially only in the form of terms that contained the meaning and substance of the maqāsid, such as the word tanattu', ta'ammuq, takalluf, maqșūd al-Shāri', aghrād, asrār, mașālih̆, mafāsid, samāhahah, and others. After that, the maqāșid conception is described in terms of meaning, as suggested by Ibn 'Āshūr, 'Allāl al-Fāsī, Raysūnī, Muhammad bin Sa'ad al-Yūbī, and others. The concept of maqāșid was later upgraded to a new discipline. Its main characteristic is by providing a foundation ontology, epistemology, and axiology.[a]

\section{BIBLIOGRAPHY}

Al-'Arabī, Abū Bakr Ibn. Aḥkām al-Qur'ān. Beirūt: Dār Al-Kutub Al'Ilmiyyah, 2003.

'Āshūr, Muhammad al-Ṭāhir Ibn. Maqāṣid al-Sharī'ah al-Islāmiyyah. Qatar: Wizārah al-Awqāf wa al-Shu'ūn al-Islāmiyyah, 2004.

'Ațiyyah, Jamāl al-Dīn. Al-Tanẓir al-Fiqhīi. Mațba'ah al-Madīnah, 1987.

Awdah, Jasser. Maqāsșid Dalīlun li al-Mubtadī. London: al-Ma'had al-'Ālamī li al-Fikr al-Islāmī, 2011.

-_- Membumikan Hukum Islam Melalui Maqāṣid As-Syarīáah. Bandung: Pustaka Mizan, 2015.

Betawi, Usman. 'Maqashid Al-Syariah Sebagai Dasar Hukum Islam aalam Pandangan Al-Syatibi dan Jasser Audha'. Jurnal Hukum Responsif 6, no. 6 (2019): 32-43.

Al-Dihlawi, Shah Waliyyullāh. Hujjatullāh al-Bāligah. Beirut: Mu'assasah 
Amir Tajrid

al-Risālah, 1984.

Farih, Amin. 'Reinterpretasi Mașlaḥah Sebagai Metode Istinbāt Hukum Islam: Studi Pemikiran Hukum Islam Abū Isḥāq Ibrāhīm Al-Shātibī'. Al-Ahkam 25, no. 1 (25 April 2015): 43. https://doi.org/10.21580/ ahkam.2015.1.25.193.

Al-Fāsī, Allāl. Maqāṣid al-Sharīah al-Islāmiyyah wa Makārimuhā. Maktabah al-Waḥdah al-'Arabiyyah al-Dār al-Bayḍ̄', 1963.

Fauzia, Ika Yunia Fauzia, and Abdul Kadir Riyadi. Prinsip-Prinsip Ekonomi Islam: Perspektif Maqāșid as-Syarī'ah. Jakarta: Prenadamedia Group, 2015.

Al-Ghazzālī, Abū Hāmid Muhammad Ibn Muhammad. Al-Mustașfā min 'Ilm al-Ușūl. Beirut: Dār al-Fikr, n.d.

Al-Hanbalī, 'Abd al-Hayy Ibn al-'Imād. Shadharāt al-Dhahab fì Akhbār Man Dhahab. Kairo: Maktabah al-Qudsi, n.d.

'Iyāḍ, Al-Qāḍ̄. Tartīb al-Madārik wa Taqrīb al-Masālik li Ma'rifāt 'A'lām Madhhab Mālik. Jilid VII. Wizārat al-Awqāf al-Maghrabiyyah, n.d.

Al-Jawziyyah, Ibn al-Qayyim. I'lām al-Muwaqqi'īn 'an Rabb al-'Ālamīn. Edited by Muḥammad Muhyyiddin 'Abdul Majīd. Beirūt: Dār al-Fikr, n.d.

———. Miftāh Dār al-Sa'ādah wa Manshūr Wilāyāt al-'Ilm wa al-Irādah. Beirut: Dār al-Kutub al-'Ilmiyyah, n.d.

Al-Jayyidī, 'Umar. Al-Tashrī’ al-Islāmī Ușūluh wa Maqāṣiduh. Manshūrāt 'Ukāz: Maṭba'ah al-Najāḥ al-Bayḍā', 1987.

Al-Juwaynī, Imām al-Haramayn. Al-Burhān fì Ușūl al-Fiqh. Edited by 'Abd al-'Azīm al-Dīb. al-Manshurah: al-Wafā', 1998.

Kayadibi, Saim. 'The State as an Essential Value (Darūriyyāt) of the Maqāṣid Al-Sharī'Ah'. Ahkam: Jurnal Ilmu Syariah 19, no. 1 (9 July 2019). https://doi.org/10.15408/ajis.v19i1.6256.

Al-Khādimī, Nūr al-Dīn Mukhtār. 'Ilm al-Maqāṣid al-Shar'Iyyah. Riyad: Maktabah al-'Ubayyikān, 2001.

———. Al-Maqāṣid al-Shar'iyyah wa Șilatuhā bi al-Adillah al-Shar'iyyah wa al-Mușțalahāt al-Ușūliyyah. Riyad: Dār Isybilia, 2003.

——_. Al-Maqāṣid fĩ al-Madhhab al-Mālikī. Riyad: Maktabah al-Rushd, 2003.

Al-Khafīf, Al-Shaykh. 'Al-Ijtihād fī al-Sharī'ah al-Islāmiyah'. In Majallāt al- 
Ijtihād fi Sharī'ah al-Islāmiyah wa Buhūth Ukhrā. Riyad, n.d.

Khallāf, 'Abd al-Wahhāb. Mașādir al-Tashrī' fì mā lā Nașșa fìh. Kuwait: Dār al-Qalam Li al-Nashr wa al-Tawzì', 1994.

Al-Khawjah, Muḥammad al-Habīb Ibn. Bayn 'Ilmay Ușūl al-Fiqh - Maqāṣid al-Islāmiyyah. Qatar: Wizārat al-Awqāf wa Al-Shu'ūn al-Islāmiyyah, n.d.

Mahsun, Mahsun. 'Rekonstruksi Pemikiran Hukum Islam Melalui Integrasi Metode Klasik dengan Metode Saintifik Modern'. Al-Ahkam 25, no. 1 (25 April 2015): 1. https://doi.org/10.21580/ahkam.2015. 1.25.191.

Al-Maqrī, Abū 'Abdullāh Muḥammad. Al-Qawāid. Edited by Aḥmad bin 'Abdullāh bin Hāmid. Makkah: Ma'had al-Buhūth wa Ihyā' al-Turāth al-Islāmī Jāmi'ah Ummu al-Qurā, n.d.

Mūsā, Muhammad Yūsuf. Tārīkh al-Fiqh al-Islāmī. Kairo: Dār al-Kutub alHadīthah, 1958.

Nur, Iffatin, Ali Abdul Wakhid, and Lestari Handayani. 'A Genealogical Analysis on the Concept and Development of Maqașid Syarī'ah'. Al'Adalah: Jurnal Syariah dan Hukum Islam 17, no. 1 (30 November 2020): 1-30. https://doi.org/10.24042/adalah.v17i1.6211.

Rabī'ah, 'Alī Ibn. 'Ilm Maqāșid al-Shārī'Ah. Riyāḍ: al-Mamlakah al'Arabiyyah al-Su'ūdiyyah, 2002.

Al-Raḥamūni, Muhammad Shārīf. Al-Rukhaș al-Fiqhiyyah min al-Qur'ān wa al-Sunnah al-Nabawiyyah. Tunis: Mațba'ah al-'Arabiyyah, 1986.

Ratna, Nyoman Kutha. Metodologi Penelitian: Kajian Budaya dan Ilmu Sosial Humaniora Pada Umumnya. Yogyakarta: Pustaka Pelajar, 2010.

Al-Raysūnī, Ahmad. Al-Fikr al-Maqāșidī: Qawā'iduh wa Fawā'iduh. Beirut: Dār al-Hādīi, 2003.

-_- Naẓariyyāt al-Maqāṣid 'Ind al-Imām al-Shāțibī. Rabāt al-Magrib: Dār al-Amān, 2003.

Rosyid, Maskur. Implementasi Konsep Maslahat Al-Tüfí dalam Fatwa MUI (2005-2010). 1st ed. Magelang: Ngudi Ilmu, 2013.

_-_. 'Membincang Kembali Hubungan Syariah dan Filsafat'. Istigha 2, no. 1 (2019): 53-54.

Rushd, Abū al-Wālid Muhammad Ibn. Bidāyah al-Mujtahid wa Nihāyah alMuqtașid. Beirut: Dār al-Fikr, n.d. 
Amir Tajrid

- - Fașl al-Maqāl wa Taqrīr ma Bayn al-Sharīah wa al-Hikmah min al-Ittișāl. Beirut: Dār al-Mashriq, 1982.

Al-Sāyis, Muhammad 'Alī. Tārīkh al-Fiqh al-Islāmī. Edited by Muḥammad al-Fātih bin Waliyyudin Al-Farfur. Damaskus: Dar al-Farfur, 2002.

Shalabī, Muḥammad Mușțafā. Ta'līl al-Aḥkām. Beirut: Dār al-Nahḍah al'Arabiyah, 1981.

Al-Shāțibī, Abū Isḥāq Ibrāhīm bin Mūsā Bin Muhammad. Al-Muwāfaqāt fì Ușūl al-Sharī’ah. Beirut: Dār al-Ma'rifah, 1975.

Syahriar, Alfa, and Zahrotun Nafisah. 'Comparison of Maqasid Al-Shari'ah Asy-Syathibi and Ibn 'Ashur Perspective of Usul Al-Fiqh Four Mazhab'. Ulul Albab: Jurnal Studi dan Penelitian Hukum Islam 3, no. 2 (30 April 2020): 185. https://doi.org/10.30659/jua.v3i2.7630.

Taymiyah, Ibn. Majmū' al-Fatāwā. Mamlakah Sa'ūdiyyah al-'Arabiyyah, n.d.

Al-'Ubaydī. Ibn Rushd wa 'Ulūm al-Sharī'ah. Beirut: Dār al-Fikr al-'Arabi, 1991.

Al-Yūbī, Muhammad Sa'ad. Maqāṣid al-Sharīah al-Islāmiyyah wa 'Alāqatuhā bi al-Adillah al-Shar'iyyah. Riyad: Dār al-Hijrah, 2002.

Zahrah, Muhammad Abū. Tārīkh al-Madhāhib al-Islāmiyah fì al-Siyāsah wa al-'Aqā'id wa Tārīkh al-Madhāhib al-Fiqhiyyah. Kairo: Dār al-Fikr al-'Arabi, 1989.

Zed, Mestika. Metode Penelitian Kepustakaan. Jakarta: Yayasan Obor Indonesia, 2008.

Al-Zurkuli, Khayr al-Dīn. Al-A'lam. Beirut: Dar al-'Ilm li al-Malayin, n.d. 